\title{
Acute kidney injury post coronary angioplasty
}

\author{
Sachin Motiram Naik 지, ${ }^{1}$ Shubham Shukla, ${ }^{1}$ Jasmine Sethi, ${ }^{1}$ Aravind Sekar ${ }^{2}$
}

'Department of Nephrology, Post Graduate Institute of Medical Education and Research, Chandigarh, India ${ }^{2}$ Department of Histopathology, Post Graduate Institute of Medical Education and Research, Chandigarh, Chandigarh, India

Correspondence to Dr Jasmine Sethi; jasmine227021@gmail.com

Accepted 8 February 2022

Check for updates

(c) BMJ Publishing Group Limited 2022. No commercial re-use. See rights and permissions. Published by BMJ.

To cite: Naik SM, Shukla S, Sethi J, et al. BMJ Case Rep 2022;15:e249294. doi:10.1136/bcr-2022249294

\section{DESCRIPTION}

A elderly women in her seventh decade, hypertensive for past 10 years, had a recent episode of ST-segment elevation myocardial infarction (MI) for which she underwent percutaneous coronary angiography with stenting of left anterior descending artery. Subsequently, she was initiated on aspirin $75 \mathrm{mg}$ daily, ticagrelor $90 \mathrm{mg}$ daily and rosuvastatin $40 \mathrm{mg}$ daily. Laboratory parameters at this time revealed serum creatinine of $95.47 \mu \mathrm{mol} / \mathrm{L}$ and normal lipid profile. Two weeks post this episode of MI, the patient presented with complaints of bilateral thigh pain and decreased urine output for past 7 days. She also gave history of brownish discolouration of urine a week prior, following which her urine output dropped to less than $100 \mathrm{~mL} /$ day (figure 1A). Current laboratory parameters revealed haemoglobin of $138 \mathrm{~g} / \mathrm{L}$, total leucocyte count of $9.9 \times 10^{9} / \mu \mathrm{L}$ and serum creatinine of $848.64 \mu \mathrm{mol} / \mathrm{L}$. Ultrasound examination showed bilateral normal sized kidneys with raised cortical echogenicity. Her urine dipstick test showed positivity for blood $(2+)$ but no erythrocytes on microscopic examination. Further, she had an elevated creatine kinase (CK) level of $38908 \mathrm{U} / \mathrm{L}$ (reference range $0-195 \mathrm{U} / \mathrm{L}$ ) and urine myoglobin of $1073 \mathrm{ng} /$ $\mathrm{mL}$ (reference range $28-72 \mathrm{ng} / \mathrm{mL}$ ). Remaining work up including antinuclear antibody (ANA), antineutrophil cytoplasmic antibody (ANCA), serum protein electrophoresis and hepatitis serology were negative. The patient denied taking any other drug, including indigenous or over the counter medications. A clinical diagnosis of statin induced rhabdomyolysis was considered based on muscle cramps, brown coloured urine, elevated muscle enzymes and urine dipstick/microscopy dissociation. We stopped rosuvastatin on day 2 and substituted ticagrelor with clopidogrel. The patient was initiated on haemodialysis via a tunnelled cuffed internal jugular catheter in view of oliguria. Gradually over next 1 week, the patient had improvement in the form of increase in urine output and declining CK levels. She was discharged after 1 week with serum creatinine of $530 \mu \mathrm{mol} / \mathrm{L}$ and haemodialysis was stopped. However, in view of non-resolving acute kidney injury (AKI), a kidney biopsy was done at week 4 that showed evidence of pigmented casts in tubules and tubular injury with severe interstitial nephritis (figure 1B). Immunohistochemistry for myoglobin pigment was positive in the tubular casts (figure 1C). Immunofluorescence was negative for immunoglobulins and complements. We initiated the patient on $1 \mathrm{mg} / \mathrm{kg}$ of prednisolone in view of interstitial nephritis. At week 6, the patient's serum creatinine had decreased to $177 \mu \mathrm{mol} / \mathrm{L}$. Steroids were tapered and stopped over next 4 weeks and the patient was advised not to take statins in future.
Dual antiplatelet agents (DAPT) and lipid lowering agents like statin are crucial in the management of acute coronary syndrome (ACS). Guidelines recommend ticagrelor in combination with aspirin for prevention of stent thrombosis in patients with ACS. ${ }^{1}$ AKI due to statin is under recognised and probably under reported as patients who receive statins are generally elderly and have many confounding factors for renal dysfunction like diabetes, hypertension and atherosclerotic renovascular disease. In addition, they receive additional drugs like renin angiotensin blockers and diuretics that can also cause AKI. Renal biopsy is seldom done in these patients as they often receive antiplatelet agents.

Statin-induced rhabdomyolysis is a severe form of muscle damage associated with very high CK levels, with myoglobinaemia and/or myoglobinuria with a concomitantly increased risk of renal failure. The risk of statin-related rhabdomyolysis is increased with increased statin dose, increased statin blood concentration, age greater than 75 years, female gender, low body mass index, hypothyroidism, chronic kidney disease and drug interactions with cytochrome P450 3A4 enzyme inhibitors. ${ }^{2}$ Among the statins, simvastatin and atorvastatin are mainly metabolised by CYP3A4 isoenzyme while rosuvastatin is metabolised by CYP2C9. Ticagrelor is metabolised by cytochrome P450 3A4, same as most of the statins and it competitively inhibits this enzyme leading to accumulation of statins metabolised by CYP 3A4. Besides inhibition of CYP3A4 isoenzymes, ticagrelor also has moderate

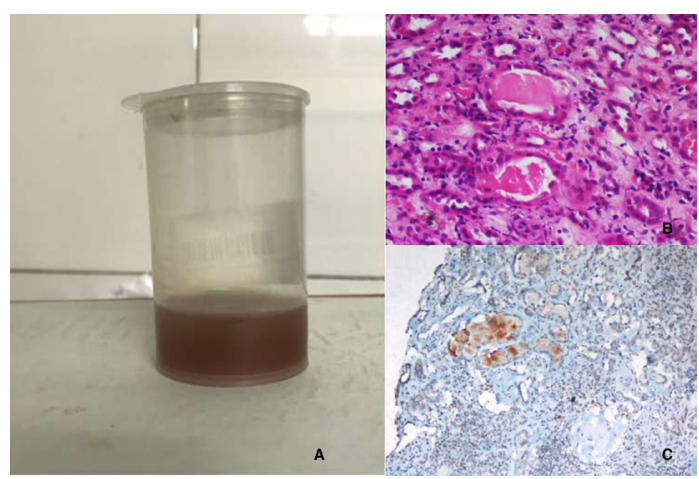

Figure 1 (A) Muddy brown discoloured urine of the patient as a result of myoglobinuria. (B) Renal biopsy depicting bright red and compact pigment casts in the tubules accompanied by interstitial inflammation and moderate degree of acute tubular injury ( $400 \mathrm{x}$, H\&E stain). (C) On immunohistochemistry, casts show strong expression for myoglobin immunomarker, indicating myoglobin pigment cast nephropathy ( $200 \mathrm{x}$, immunoperoxidase). 
CYP2C9-inhibiting properties in vitro. ${ }^{3}$ Apart from this, other potential mechanisms like inhibition of organic anion transporter polypeptides (OATPs) and P glycoprotein (P-gp) has been also proposed for interaction between ticagrelor and statins. This drug interaction explains the increased risk of statin-related muscle toxicity with concomitant use of ticagrelor. ${ }^{3}$

The prime suspect for AKI due to statins is rhabdomyolysis. However, the data from Jupiter study showed that only $0.01 \%$ of patients who received rosuvastatin $20 \mathrm{mg}$ developed rhabdomyolysis while AKI was seen in $0.21 \%$ of patients. ${ }^{4}$ Thus, indicating that rhabdomyolysis does not account for AKI in all patients. Another possible mechanism is a direct or immune mediated acute or subacute tubulointerstitial nephritis (TIN). There is a published literature in which rosuvastatin caused AKI due to TIN which resolved after drug withdrawal and treatment with steroids. ${ }^{5}$ Our case is rare as the patient had developed both rhabdomyolysis as a possible rosuvastatin side effect potentiated by ticagrelor and statin-induced TIN. This case emphasises the role of kidney biopsy in cases of non-resolving AKI. Clinicians should be aware of the potential renal toxicity of statins especially at high doses. It is a good practice to measure CK before prescribing statin to identify those at potential risk of myopathy. One should be vigilant and routinely monitor renal function tests during the first few months after initiation of high dose statin.

Contributors SN, SS are the first Joint coauthors. They jointly contributed in manuscript writing. AS helped in histopathology image acquisition. JS contributed in final edits and proof reading.

Funding The authors have not declared a specific grant for this research from any funding agency in the public, commercial or not-for-profit sectors.

Competing interests None declared.

Patient consent for publication Consent obtained directly from patient(s).

Provenance and peer review Not commissioned; externally peer reviewed.

Case reports provide a valuable learning resource for the scientific community and can indicate areas of interest for future research. They should not be used in isolation to guide treatment choices or public health policy.

\section{ORCID iD}

Sachin Motiram Naik http://orcid.org/0000-0001-7429-613X

\section{REFERENCES}

1 Valgimigli M, Bueno H, Byrne RA, et al. 2017 ESC focused update on dual antiplatelet therapy in coronary artery disease developed in collaboration with EACTS: the task force for dual antiplatelet therapy in coronary artery disease of the European Society of cardiology (ESC) and of the European association for Cardio-Thoracic surgery (EACTS). Eur Heart J 2018;39:213-60.

2 Danielak D, Karaźniewicz-Łada M, Główka F. Assessment of the risk of rhabdomyolysis and myopathy during concomitant treatment with ticagrelor and statins. Drugs 2018;78:1105-12.

3 Kariyanna PT, Haseeb S, Chowdhury YS, et al. Ticagrelor and statin interaction induces rhabdomyolysis and acute renal failure: case reports and scoping review. Am J Med Case Rep 2019;7:337-41.

4 Ridker PM, Danielson E, Fonseca FAH, et al. Rosuvastatin to prevent vascular events in men and women with elevated C-reactive protein. N Engl J Med 2008;359:2195-207.

5 Annigeri RA, Mani RM. Acute interstitial nephritis due to statin and its class effect. Indian J Nephrol 2015;25:54-6.

Copyright 2022 BMJ Publishing Group. All rights reserved. For permission to reuse any of this content visit

https://www.bmj.com/company/products-services/rights-and-licensing/permissions/

BMJ Case Report Fellows may re-use this article for personal use and teaching without any further permission.

Become a Fellow of BMJ Case Reports today and you can:

- Submit as many cases as you like

- Enjoy fast sympathetic peer review and rapid publication of accepted articles

- Access all the published articles

- Re-use any of the published material for personal use and teaching without further permission

Customer Service

If you have any further queries about your subscription, please contact our customer services team on +44 (0) 2071111105 or via email at support@bmj.com.

Visit casereports.bmj.com for more articles like this and to become a Fellow 